\title{
Expression of VPAC1 in a murine model of allergic asthma
}

\author{
Hans D Lauenstein ${ }^{1,2}$, David Quarcoo ${ }^{3}$, Tobias Welte ${ }^{1}$, Armin Braun ${ }^{2}$ and David A Groneberg ${ }^{3 *}$
}

\begin{abstract}
Vasoactive intestinal polypeptide (VIP) is a putative neurotransmitter of the inhibitory non-adrenergic noncholinergic nervous system and influences the mammalian airway function in various ways. Hence known for bronchodilatory, immunomodulatory and mucus secretion modulating effects by interacting with the VIP receptors VPAC1 and VPAC2, it is discussed to be a promising target for pharmaceutical intervention in common diseases such as COPD and bronchial asthma. Here we examined the expression and transcriptional regulation of VPAC1 in the lungs of allergic mice using an ovalbumin (OVA) -induced model of allergic asthma. Mice were sensitized to OVA and challenged with an OVA aerosol. In parallel a control group was sham sensitized with saline. VPAC1 expression was examined using RT-PCR and real time-PCR studies were performed to quantify gene transcription. VPAC1 mRNA expression was detected in all samples of OVA-sensitized and challenged animals and control tissues. Further realtime analysis did not show significant differences at the transcriptional level.

Although the present studies did not indicate a major transcriptional regulation of VPAC1 in states of allergic airway inflammation, immunomodulatory effects of VPAC1 might still be present due to regulations at the translational level.
\end{abstract}

Keywords: VIP, VPAC1, Neurotransmitter, Asthma, Allergy

\section{Introduction}

Respiratory diseases constitute a major part of occupational diseases. Next to asbestosis [1,2] and tuberculosis [3,4], bronchial asthma belongs to leading causes of the global burden of occupational lung disease [5-7] and further insights into the underlying mechanisms of the disease are needed. Among these mechanisms, pathways of the neuroimmune axis may play a key role. In this respect, vasoactive intestinal peptide (VIP) is a putative neurotransmitter of the non-adrenergic non-cholinergic nervous system in the respiratory tract [8]. VIP-immunoreactivity is present in cells of the tracheobronchial smooth muscle layer, in the walls of pulmonary and bronchial vessels, around submucosal glands, in the lamina propria and in pulmonary ganglia $[8,9]$. VIP immuno reactive nerve fibres are found as branching networks in the respiratory tract [8] and they are decreasing in frequency as the airways become smaller, but extend to peripheral bronchiols $[10,11]$. VIPergic nerves are

\footnotetext{
* Correspondence: arbsozmed@med.uni-frankfurt.de

${ }^{3}$ Institute of Occupational Medicine, Social Medicine and Environmental Medicine, Medical School, Goethe-University Frankfurt, Frankfurt, Germany Full list of author information is available at the end of the article
}

colocalized with cholinergic nerves and VIP immunoreactivity is also present in sensory nerves $[8,12]$.

VIP is a highly abundent and pleiotrophic mediator, known for various effects, including bronchodilatation, modulation of mucus secretion and immunomodulation. VIP is therefore a promising target for future therapy in chronic inflammatory lung diseases [13].

VIP binds predominantly to the two VIP-receptors VPAC1 and VPAC2. Antiinflammatory effects have been demonstrated to be mediated by the VPAC1 receptor in vivo and in vitro. VPAC1 activation was shown to inhibit the release of inflammatory mediators from macrophages like IL-6, TNF-alpha, IL-12 and NO and increase of IL-10 in a murine model of septic shock. In contrast to VPAC2, VPAC1 also inhibits the proliferation of activated $\mathrm{T}$ cells and the expression of costimulatory molecules like B7.1 and B7.2 [14]. A reduction of VPAC1 expression could be shown for $\mathrm{T}$ cells in case of activation [15].

Since VPAC1 was suggested to play the major role in the antiinflammatory action of VIP [16] and anti-inflammatory effects were recently described for the receptor PAC1, the present study assessed the expression and regulation of the

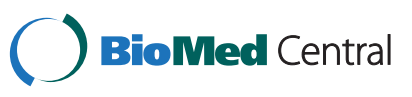


receptor VPAC1 [17] in a murine model of asthma on the transcriptional level.

\section{Material and methods}

Asthma Model and preparation of lung tissue samples

Female BALB/c mice were sensitized to ovalbumin (OVA) as previously described [17] by administration of $10 \mu \mathrm{g}$ OVA and 1,5 mg Alum (Pierce, Rockford, USA) in $50 \mu \mathrm{L}$ saline by intraperitoneal injection on days 0,14 and $21(n=16)$ (Figure 1$)$. The allergic response in the respiratory tract was induced by the exposition of mice to 1\% OVA aerosol for $20 \mathrm{~min}$ on days 27 and 28 . 24 hours after the last challenge the mice were sacrificed by an overdose of Narcoren, (Merial, Hallbergmoos, Germany). Lungs were then removed. The upper right lobe was dissected and snap frozen in liquid nitrogen. The samples were stored at $-80^{\circ} \mathrm{C}$ until further analysis. The animal study was performed according to internationally recognized guidelines and approved by the local authorities (Hannover).

\section{Generation of cDNA}

As previously described [17], the lung samples were homogenized using fastprep (Bio101, Carlsbad, USA) and total RNA was isolated using the RNeasy mini kit (Qiagen, Hilden, Germany) according to the customer's manual. Quantity of RNA was controlled photometrically by OD $260 / 280 \mathrm{~nm}$.

900 ng RNA were transcribed into cDNA using the omniscript RT-PCR kit (Qiagen, Hilden, Germany). RNA was denatured at $65^{\circ} \mathrm{C}$ for 5 minutes. After cooling to room temperature, buffer RT, random primers, RNase inhibitor, and omniscript for the RT-PCR were added. The RNA was transcribed at $37^{\circ} \mathrm{C}$ for $90 \mathrm{~min}$ and the reaction was stopped by heating up to $95^{\circ} \mathrm{C}$ for $5 \mathrm{~min}$. Each RNA sample was used for two approaches: First for the RT-PCR and in a second approach as a RNA control for genomic DNA contamination in which samples were treated like the RT-PCR samples but without the transcriptase. Both, the cDNA and the RNA control were immediately used for the real time-PCR.

\section{Quantitative real time PCR}

The relative amounts of cDNA were quantified using the Light Cycler Fast Start SYBR Green Kit (Roche, Mannheim, Germany) according to the customer's protocol. Porphobilinogen deaminase (PBGD) was used as a house keeping gene. The DNA was amplified using the following conditions: 10 in $95^{\circ} \mathrm{C}$; 45 cycles $1 \mathrm{~s} 95^{\circ} \mathrm{C}, 10 \mathrm{~s} 68^{\circ} \mathrm{C}, 9 \mathrm{~s}$ $72^{\circ} \mathrm{C}$. The pureness of the products was verified via a melting curve. The products were visualized via gel electrophoresis.

All primers were produced by MWG (Ebersberg, Germany) and designed intron spanning to exclude the amplification of genomic DNA in case of contaminations. The PCR products were verified by DNA agarose gel and by sequencing by the company GATC biotech (Koblenz, Germany). The primer sequences are shown in Table 1.

\section{Results and discussion}

Specific PCR products for VPAC1 and PBGD were found in the lungs of both, the OVA sensitized and the saline sensitized control group. The products were identified to be specific by gel electrophoresis (Figure 2) and by melting curve analysis (data not shown).

To assess quantitative changes of VPAC1 mRNA expression, the VPAC1 fluorescence signal was normalized to the house keeping gene PBGD using the program rel quant (Roche) and displayed as relative unit. Though the real time PCR results tend to show a slight increase of VPAC1 expression in the lungs of OVA sensitized animals compared to the sham sensitized group (Figure 3), no significant difference can be detected using statistical approaches.

Although a clear alteration in the VPAC 1 expression on RNA level could not be detected in the present study, differential VPAC1 expression in terms of inflammatory mechanisms had been shown before. In this respect, in an in vitro model with different subsets of $\mathrm{T}$ cell subsets the VPAC1 expression was linked to an inhibition of proliferation and the expression of costimulatory molecules [14]. VPAC1 was also shown to be downregulated in case of activation of T cells [15].

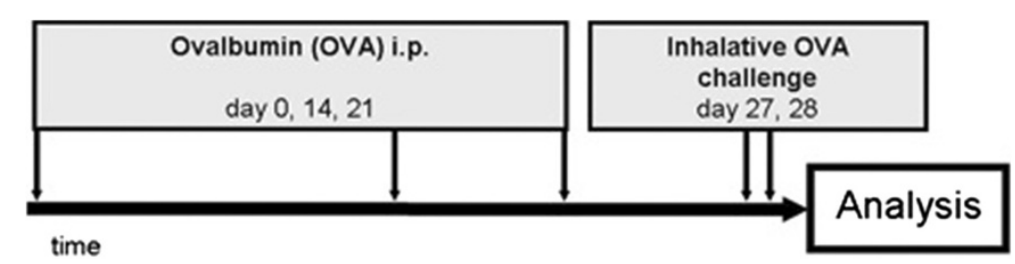

Figure 1 Treatment protocol for the murine asthma model; OVA sensitization via i.p administration of $10 \mathrm{mg}$ OVA on days 0 , 14 and 21 followed by aerosolic challenges with an 1\% OVA aerosol for $20 \mathrm{~min}$ on days 27 and 28; sacrifice on day 29. 
Table 1 Primer sequences

\begin{tabular}{llll}
\hline Gene & Primer forward & Primer reverse & $\begin{array}{l}\text { Product } \\
\text { size }\end{array}$ \\
\hline PBGD & cacgatcctgaaactctgct & agatggtccagaagatgaccc & 224 \\
PAC1 & ttcactactgcgtggtgtccaact & atatcccagcatcccgcatcatca & 228 \\
\hline
\end{tabular}

VPAC1 expression was shown in various cells of the immune system like T cells and B cells in other compartments of the body such as the intestinal system [18]. Also the infiltration of these VPAC1-positive cells during an inflammation like in ulcerative colitis and crohn's disease was shown to increase the amount of VPAC1 positive cells in the inflammed tissue [18].

According to literature it could be hypothesized, that VPAC1 might play a role in the pathogenesis of bronchial asthma, for effects mediated by VPAC1 are present in allergic diseases such as asthma or atopic dermatitis. Nevertheless we did not find a regulation of VPAC1 on the transcriptional level so far. Therefore, it is necessary to take a more detailed look into the lung tissue on the single cellular level and VPAC1 positive cells and the expression of VPAC1 should be quantified for each cell population separately. Overlaps of alterations in VPAC1 expression in specific cell populations by the influx of VPAC1 positive cells could thereby avoided. Also, regulation may take place at the level of translation and future studies should access this aspect.

Interestingly, the VPAC1 related receptor PAC1 was recently shown to be differentially expressed in a murine model of ovalbumin-induced asthma [17]. In this study an increased PAC1R mRNA expression was present in lung tissue under allergic conditions. In the state of an asthmatic reaction, PAC1R-deficient mice $(\operatorname{PAC} 1 \mathrm{R}(-/-))$ and to $\mathrm{BALB} / \mathrm{c}$ mice treated with the specific PAC1R agonist maxadilan, PAC1R deficiency resulted in increased inflammatory effects, while agonistic stimulation

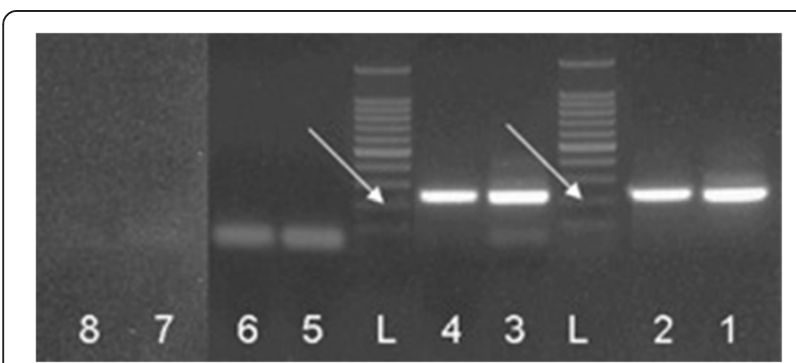

Figure 2 VPAC1 gel electrophoresis; $L=100$ bp DNA ladder; arrows point at 200 bp band; slot $1=$ OVA sensitized (OVs) PBGD; slot 2 = OVs VPAC1; slot 3 = sham sensitized (SHs) PBGD; slot $4=$ SHs VPAC1; slot $5=$ OVs PBGD RNA control (RC); slot $6=$ OVs VPAC1 RC; slot 7 = SHs PBGD RC; slot 8 = SHs VPAC1 RC; expected products: $\mathrm{PBGD}=224 \mathrm{bp}$; $\mathrm{VPAC1}=228 \mathrm{bp}$.

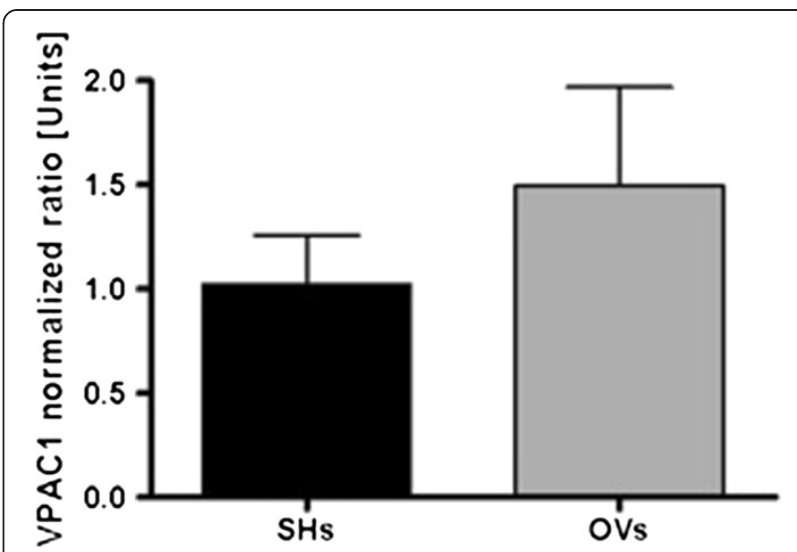

Figure 3 Normalized ratio of VPAC1 expression in lung tissue; VPAC1 fluorescence signal normalized to PBGD; OVs = OVA sensitized and challenged group, $\mathrm{SHs}=$ sham sensitized group.

of It was therefore concluded that anti-inflammatory effects can be achieved via PAC1 receptor and that PAC1receptor agonists may represent a promising target for an anti-inflammatory therapy.

In summary, the present analysed the expression and transcriptional regulation of VPAC1 in a murine model of allergic asthma using an established ovalbumin protocol. While VPAC1 mRNA expression was detected in all samples realtime analysis did not show significant differences at the transcriptional level. Therefore further studies should quantify VPAC1 expression on the level of single respiratory cells using modern tools of biochemistry [19], molecular biology [20], cell biology [21][22] and morphology [23].

\section{Competing interests}

The authors declare that they have no competing interests.

\section{Authors' contributions}

$H D L, D Q, T W, A B, D A G$ have made substantial contributions to the conception and design of the study, acquisition of the data and interpretation. HDL, DQ, TW, AB, DAG have been involved in drafting and revising the manuscript. All authors have read and approved the final manuscript.

\section{Acknowledgement}

Supported by a grant of the Deutsche Forschungsgemeinschaft: SFB 587 Immune reactions of the Lung in Infection and Allergy.

\section{Author details}

'Department of Pulmonary Medicine, Hannover Medical School, Hannover, Germany. ${ }^{2}$ Fraunhofer Institute of Toxicology and Experimental Medicine, Hannover, Germany. ${ }^{3}$ Institute of Occupational Medicine, Social Medicine and Environmental Medicine, Medical School, Goethe-University Frankfurt, Frankfurt, Germany.

Received: 11 October 2012 Accepted: 30 September 2013 Published: 10 October 2013 


\section{Reference}

1. Wilken D, Velasco Garrido M, Manuwald U, Baur X: Lung function in asbestos-exposed workers, a systematic review and meta-analysis. J Occup Med Toxicol 2011, 6:21.

2. Alexopoulos EC, Bouros D, Dimadi M, Serbescu A, Bakoyannis G, Kokkinis FP: Comparative analysis of induced sputum and bronchoalveolar lavage fluid (BALF) profile in asbestos exposed workers. J Occup Med Toxicol 2011, 6:23.

3. Moucaut A, Nienhaus A, Courtois B, Nael V, Longuenesse C, Ripault B, Rucay $P$, Moisan $S$, Roquelaure $Y$, Tripodi D: The effect of introducing IGRA to screen French healthcare workers for tuberculosis and potential conclusions for the work organisation. J Occup Med Toxicol 2013, 8:12.

4. Nienhaus A, Costa JT: Screening for tuberculosis and the use of a borderline zone for the interpretation of the interferon-gamma release assay (IGRA) in Portuguese healthcare workers. J Occup Med Toxicol 2013, 8:1.

5. Baur X: A compendium of causative agents of occupational asthma. J Occup Med Toxicol 2013, 8:15.

6. Baur X, Barbinova L: Occupational airborne exposure, specific sensitization and the atopic status: evidence of a complex interrelationship. J Occup Med Toxicol 2013, 8:2.

7. Baur X, Bakehe P, Vellguth H: Bronchial asthma and COPD due to irritants in the workplace - an evidence-based approach. J Occup Med Toxicol 2012, 7:19.

8. Maggi CA: The mammalian tachykinin receptors. Gen Pharmacol 1995, 26:911-944.

9. Groneberg DA, Springer J, Fischer A: Vasoactive intestinal polypeptide as mediator of asthma. PulmPharmacol Ther 2001, 14:391-401.

10. Lundberg JM, Fahrenkrug J, Hokfelt T, Martling CR, Larsson O, Tatemoto K, Anggard $\mathrm{A}$ : Co-existence of peptide $\mathrm{HI}(\mathrm{PHI})$ and VIP in nerves regulating blood flow and bronchial smooth muscle tone in various mammals including man. Peptides 1984, 5:593-606.

11. Lundberg JM, Fahrenkrug J, Larsson O, Anggard A: Corelease of vasoactive intestinal polypeptide and peptide histidine isoleucine in relation to atropine-resistant vasodilation in cat submandibular salivary gland. Neurosci Lett 1984, 52:37-42.

12. Groneberg DA, Quarcoo D, Frossard N, Fischer A: Neurogenic mechanisms in bronchial inflammatory diseases. Allergy 2004, 59:1139-1152.

13. Groneberg DA, Rabe KF, Fischer A: Novel concepts of neuropeptide-based drug therapy: vasoactive intestinal polypeptide and its receptors. Eur J Pharmacol 2006, 533:182-194.

14. Delgado M, Gomariz RP, Martinez C, Abad C, Leceta J: Anti-inflammatory properties of the type 1 and type 2 vasoactive intestinal peptide receptors: role in lethal endotoxic shock. Eur J Immunol 2000, 30:3236-3246.

15. Sun W, Hong J, Zang YC, Liu X, Zhang JZ: Altered expression of vasoactive intestinal peptide receptors in T lymphocytes and aberrant Th1 immunity in multiple sclerosis. Int Immunol 2006, 18:1691-1700.

16. Delgado M, Ganea D: Vasoactive intestinal peptide and pituitary adenylate cyclase-activating polypeptide inhibit antigen-induced apoptosis of mature T lymphocytes by inhibiting Fas ligand expression J Immunol 2000, 164:1200-1210.

17. Lauenstein HD, Quarcoo D, Plappert L, Schleh C, Nassimi M, Pilzner C, Rochlitzer S, Brabet P, Welte T, Hoymann HG, et al: Pituitary adenylate cyclase-activating peptide receptor 1 mediates anti-inflammatory effects in allergic airway inflammation in mice. Clin Exp Allergy 2011, 41:592-601.

18. Yukawa T, Oshitani N, Yamagami H, Watanabe K, Higuchi K, Arakawa T: Differential expression of vasoactive intestinal peptide receptor 1 expression in inflammatory bowel disease. Int J Mol Med 2007, 20:161-167.

19. De Vries A, Engels F, Henricks PA, Leusink-Muis T, McGregor GP, Braun A, Groneberg DA, Dessing MC, Nijkamp FP, Fischer A: Airway hyperresponsiveness in allergic asthma in guinea-pigs is mediated by nerve growth factor via the induction of substance P: a potential role for trkA. Clin Exp Allergy 2006, 36:1192-1200.

20. Groneberg DA, Doring F, Nickolaus M, Daniel H, Fischer A: Expression of PEPT2 peptide transporter mRNA and protein in glial cells of rat dorsal root ganglia. Neurosci Lett 2001, 304:181-184.

21. Springer J, Scholz FR, Peiser C, Groneberg DA, Fischer A: SMAD-signaling in chronic obstructive pulmonary disease: transcriptional down-regulation of inhibitory SMAD 6 and 7 by cigarette smoke. Biol Chem 2004, 385:649-653.

22. Eynott PR, Groneberg DA, Caramori G, Adcock IM, Donnelly LE, Kharitonov S, Barnes PJ, Chung KF: Role of nitric oxide in allergic inflammation and bronchial hyperresponsiveness. Eur J Pharmacol 2002, 452:123-133.

23. Groneberg DA, Peiser C, Dinh QT, Matthias J, Eynott PR, Heppt W, Carlstedt I, Witt C, Fischer A, Chung KF: Distribution of respiratory mucin proteins in human nasal mucosa. Laryngoscope 2003, 113:520-524.

doi:10.1186/1745-6673-8-28

Cite this article as: Lauenstein et al:: Expression of VPAC1 in a murine model of allergic asthma. Journal of Occupational Medicine and Toxicology 2013 8:28.

\section{Submit your next manuscript to BioMed Central and take full advantage of:}

- Convenient online submission

- Thorough peer review

- No space constraints or color figure charges

- Immediate publication on acceptance

- Inclusion in PubMed, CAS, Scopus and Google Scholar

- Research which is freely available for redistribution 